\title{
Ligand Synthesis Catalyst and Complex Metal Ion: Multicomponent Synthesis of 1,3-Bis(4-phenyl-[1,2,3] triazol-1-yl)-propan-2-ol Copper(I) Complex and Application in Copper-Catalyzed Alkyne-Azide Cycloaddition
}

\author{
María Teresa Ramírez-Palma, Jesús Segura-Arzate, \\ Gustavo López-Téllez, and Erick Cuevas-Yañez \\ Centro Conjunto de Investigación en Química Sustentable UAEM-UNAM, Carretera Toluca-Atlacomulco Km. 14.5,
} 50200 Toluca, MEX, Mexico

Correspondence should be addressed to Erick Cuevas-Yañez; ecuevasy@uaemex.mx

Received 2 February 2016; Revised 9 April 2016; Accepted 10 April 2016

Academic Editor: Henryk Kozlowski

Copyright (c) 2016 María Teresa Ramírez-Palma et al. This is an open access article distributed under the Creative Commons Attribution License, which permits unrestricted use, distribution, and reproduction in any medium, provided the original work is properly cited.

\begin{abstract}
A new bistriazole copper complex was synthesized by direct treatment of an alkyne, an azide, and CuI as copper salt through in situ ligand formation under a multicomponent reaction process. This complex was analyzed by XPS, TGA, DSC, and SEM techniques and revealed a triangular-shaped morphology, high thermal stability, and catalytic power in CuAAC reactions, requiring only $2.5 \%$ mol catalyst to afford 1,2,3-triazoles in good yields which can be reused at least for 4 cycles.
\end{abstract}

\section{Introduction}

Multicomponent reactions (MCRs) represent one of the growing synthetic approaches due to the fact that they provide useful products through the expeditious creation of multiple bonds in a one-pot reaction [1]. Under this concept, many reagents are added in only one step and they selectively react to give only one reaction product [2]. This approach has been successfully applied in the organic chemistry field [3, 4]; however, few examples of this synthetic strategy are found in the preparation of metal complexes. A relevant case was described by the group of Xiong and Abrahams to prepare tetrazole metal complexes from nitriles, sodium azide, and diverse metal salts [5].

On the other hand, Click Chemistry through coppercatalyzed alkyne-azide cycloaddition (CuAAC) has been recognized as the most important method developed in this century for creating new molecules and chemical libraries as well as macromolecular diversified architectures with high efficiency in terms of yield and atom economy [6]. In spite of all these advantages, the potential of Click Chemistry could be further increased by combining with multicomponent reactions towards synthesis of sophisticated materials, particularly metal catalysts.

In connection with other synthetic studies, we prepared an array of bistriazoles derived from diazidopropanol using $\mathrm{CuAAC}$ reaction. During the reaction work-up, we noticed that copper catalyst was difficult to remove in these compounds, probably owing to complex formation between product and catalyst. This feature encouraged us to explore this process in order to devise a simple method for the preparation of a sort of novel bistriazole copper(I) complexes from the in situ ligand synthesis into a multicomponent reactions concept. Herein is described our recent endeavors in this area.

\section{Experimental Section}

The starting materials were purchased from Aldrich Chemical Co. and were used without further purification. Solvents 
were distilled before use. Silica plates of $0.20 \mathrm{~mm}$ thickness were used for thin layer chromatography. Melting points were determined with a Fisher-Johns melting point apparatus and they are uncorrected. ${ }^{1} \mathrm{H}$ and ${ }^{13} \mathrm{C}$ NMR spectra were recorded using Varian 500; the chemical shifts $(\delta)$ are given in ppm relative to TMS as internal standard (0.00). For analytical purposes, the mass spectra were recorded on Shimadzu GCMS-QP2010 Plus in the EI mode, $70 \mathrm{eV}, 200^{\circ} \mathrm{C}$ via direct inlet probe. Only the molecular and parent ions $(\mathrm{m} / z)$ are reported. IR spectra were recorded on Bruker Tensor 27 equipment. The XPS wide and narrow spectra were acquired using JEOL JPS-9200, equipped with a Mg $\mathrm{X}$-ray source $(1253.6 \mathrm{eV})$ at $300 \mathrm{~W}$, the area of analysis was $3 \mathrm{~mm}^{2}$, and the vacuum was in the order of $7.5 \times 10^{-9}$ Torr for all samples. The spectra were analyzed using the SpecSurf ${ }^{\mathrm{TM}}$ software included with the instrument; all spectra were charge-corrected by means of the adventitious carbon signal (Cls) at $284.5 \mathrm{eV}$. The shirley method was used for the background subtraction, whereas for the curve fitting the Gauss-Lorentz method was used. TGA/DSC studies were carried out in thermal analyzer Netzsch STA 449 F3 Jupiter with a heating ramp of $10^{\circ} \mathrm{C} / \mathrm{min}$, in a nitrogen atmosphere at a flow rate of $20 \mathrm{~mL} / \mathrm{min}$. Samples were heated from room temperature to $560^{\circ} \mathrm{C}$; aluminum crucibles of $5 \mathrm{~mm}$ diameter were used. Savitzky-Golay smoothing algorithm was employed for TGA curves. 1,3-Diazido-propan-2-ol (13) was synthesized according to a previous report [7].

Synthesis of Copper(I) Complex of 1,3-Bis(4-phenyl-[1,2,3]triazol-1-yl)-propan-2-ol (4). To a solution of 1,3-diazido-propan-2-ol [7] (0.142 g, $1 \mathrm{mmol})$ in $\mathrm{MeOH}(15 \mathrm{~mL})$ were added successively phenylacetylene $(0.22 \mathrm{~mL}, 0.204 \mathrm{~g}, 2 \mathrm{mmol})$, $0.5 \mathrm{~N}$ aqueous solution of $\mathrm{NaOH}(0.2 \mathrm{~mL})$, and $\mathrm{CuI}(0.189 \mathrm{~g}$, $1 \mathrm{mmol})$. The resulting mixture was stirred for 24 hours at room temperature under a nitrogen atmosphere. The solid was filtered and washed with cold $\mathrm{MeOH}(20 \mathrm{~mL})$ and diethyl ether $(20 \mathrm{~mL})$. The product was dried under reduced pressure. Yield: $0.335 \mathrm{~g}(97 \%)$, m.p. $180^{\circ} \mathrm{C}$. IR (ATR) $\nu_{\max } / \mathrm{cm}^{-1}: 3369,3122,1440,1227,1157 .{ }^{1} \mathrm{H}$ NMR: $(500 \mathrm{MHz}$, DMSO-d 6 ) $\delta 8.59(\mathrm{~s}, 2 \mathrm{H}), 7.89(\mathrm{~s}, 4 \mathrm{H}), 7.44(\mathrm{~s}, 4 \mathrm{H}), 7.34(\mathrm{~s}$, $2 \mathrm{H}), 5.85$ (s, 1H), 4.67 (s, 2H), $4.45(\mathrm{~s}, 2 \mathrm{H}), 3.15(\mathrm{~s}, 1 \mathrm{H}) .{ }^{13} \mathrm{C}$ NMR: (125 MHz, DMSO-d $\left._{6}\right) \delta 146.1,130.8,128.9,127.8,125.1$, 122.5, 68.3, 53.2. Anal. Calcd for $\mathrm{C}_{19} \mathrm{H}_{18} \mathrm{CuIN}_{6} \mathrm{O}$ (\%): C, 42.51; H, 3.38; N, 15.65. Found: C, 72.05; H, 11.50; N, 7.67. HRMS: calcd. for $\mathrm{C}_{19} \mathrm{H}_{18} \mathrm{CuIN}_{6} \mathrm{O}[\mathrm{M}]^{+}$: 535.9983, found: 535.9989 .

Synthesis of 1,2,3-Triazoles Catalyzed by 1,3-Bis(4-phenyl[1,2,3]triazol-1-yl)-propan-2-ol Copper(I) Complex: General Procedure. The copper complex 4 (0.0268 g, $0.025 \mathrm{mmol})$ was added to a stirred solution containing the corresponding alkyne $(1.0 \mathrm{mmol})$ and the appropriate azide $(1.05 \mathrm{mmol})$ in $\mathrm{CH}_{2} \mathrm{Cl}_{2}(10 \mathrm{~mL})$. The resulting reaction mixture was stirred at room temperature for $24 \mathrm{~h}$. The mixture was filtered through celite-activated charcoal. The solvent was removed under reduced pressure and the final product was purified by crystallization.

1-Benzyl-4-phenyl-1,2,3-triazole (6). Phenylacetylene and benzyl azide afforded 1-benzyl-4-phenyl-1,2,3-triazole as white solid. Yield: $132.8 \mathrm{mg}$ (99\%). m. p. $130^{\circ} \mathrm{C}$ (lit. 130$130.9^{\circ} \mathrm{C}$ ) [8]. IR (ATR) $v_{\max } / \mathrm{cm}^{-1}: 3140,3028,2974,1606$, 1579, 1489. ${ }^{1} \mathrm{H}$ NMR (300 MHz, $\left.\mathrm{CDCl}_{3}\right) \delta / \mathrm{ppm}: 7.78-7.81(\mathrm{~m}$, 2H), $7.66(\mathrm{~s}, 1 \mathrm{H}), 7.41-7.36(\mathrm{~m}, 3 \mathrm{H}), 7.32-7.25(\mathrm{~m}, 5 \mathrm{H}), 5.55(\mathrm{~s}$, 2H). ${ }^{13} \mathrm{C}$ NMR $\left(75 \mathrm{MHz}, \mathrm{CDCl}_{3}\right) \delta / \mathrm{ppm}: 148.2,134.7,130.5$, 129.1, 128.7, 128.1, 127.9, 125.6, 119.5, 54.1. MS $\left(\mathrm{EI}^{+}\right) \mathrm{m} / z(\%)$ : $235[\mathrm{M}]^{+}(20), 206\left[\mathrm{M}-\mathrm{HN}_{2}\right]^{+}(74), 116\left[\mathrm{M}-\mathrm{C}_{6} \mathrm{H}_{5} \mathrm{~N}_{3}\right]^{+}(100)$, $91\left[\mathrm{C}_{6} \mathrm{H}_{5} \mathrm{CH}_{2}\right]^{+}(85)$.

1-(1-Benzyl-[1,2,3]triazol-4-yl)-cyclohexanol (7). 1-Ethynylcyclohexanol and benzyl azide afforded 1-(1-benzyl-[1,2,3]triazol-4-yl)-cyclohexanol as white solid. Yield: $244.4 \mathrm{mg}$ (95\%). m. p. $150^{\circ} \mathrm{C}$. IR (ATR) $v_{\max } / \mathrm{cm}^{-1}: 3386,3291,2930,2855,1604$. ${ }^{1} \mathrm{H}$ NMR (300 MHz, DMSO-d 6 ) $/$ ppm: $7.98(\mathrm{~s}, 1 \mathrm{H}), 7.39(\mathrm{~m}$, $5 \mathrm{H}), 5.60$ (s, 1H), $4.92(\mathrm{~s}, 1 \mathrm{H}), 1.92-1.46(\mathrm{~m}, 10 \mathrm{H}) .{ }^{13} \mathrm{C} \mathrm{NMR}$ (75 MHz, DMSO-d 6 ) $\delta / p p m: 136.2,128.7,128.5,128.0,121.1$, 68.0, 52.7, 37.8, 25.224, 21.6. MS (EI $\left.{ }^{+}\right) \mathrm{m} / z(\%): 257[\mathrm{M}]^{+}(20)$, $91\left[\mathrm{C}_{6} \mathrm{H}_{5} \mathrm{CH}_{2}\right]^{+}$(100). HRMS (EI): calcd. for $\mathrm{C}_{15} \mathrm{H}_{19} \mathrm{~N}_{3} \mathrm{O}$ : 257.1528; found: 257.1534 .

1-Benzyl-4-(4-bromophenoxymethyl)-[1,2,3]triazole (8). 1-Bromo-4-prop-2-ynyloxy-benzene and benzyl azide afforded 1benzyl-4-(4-bromophenoxymethyl)-[1,2,3] triazole as white solid. Yield: $116.6 \mathrm{mg}$ (34\%). 109-110 C. IR (ATR) $v_{\max } / \mathrm{cm}^{-1}$ : 3040, 2954, 2926, 2873, 1581, 1487. ${ }^{1} \mathrm{H}$ NMR $(300 \mathrm{MHz}$, $\mathrm{CDCl}_{3}$ ) $\delta / \mathrm{ppm}: 7.51(\mathrm{~s}, 1 \mathrm{H}), 7.33-7.38(\mathrm{~m}, 3 \mathrm{H}), 7.27-7.30(\mathrm{~m}$, $2 \mathrm{H}), 7.25-7.27(\mathrm{~d}, 2 \mathrm{H}, J=8.3 \mathrm{~Hz}), 6.81-6.85(\mathrm{~d}, 2 \mathrm{H}, J=$ $8.2 \mathrm{~Hz}), 5.52$ (s, 2H), $5.14(\mathrm{~s}, 2 \mathrm{H}) .{ }^{13} \mathrm{C} \mathrm{NMR}\left(75 \mathrm{MHz}, \mathrm{CDCl}_{3}\right.$ ) $\delta /$ ppm: 157.3, 144.2, 134.4, 132.3, 129.2, 128.9, 128.1, 122.7, 116.6, 113.5, 62.2, 54.3. MS $\left(\mathrm{EI}^{+}\right) \mathrm{m} / z(\%): 343[\mathrm{M}]^{+}(5), 172[\mathrm{M}-$ $\left.\mathrm{C}_{6} \mathrm{H}_{4} \mathrm{BrO}\right]^{+}$(15), $144\left[\mathrm{M}-\mathrm{C}_{8} \mathrm{H}_{8} \mathrm{BrO}\right]^{+}$(65), $91\left[\mathrm{C}_{6} \mathrm{H}_{5} \mathrm{CH}_{2}\right]^{+}$ (100).

1-Benzyl-4-(4-chlorophenoxymethyl)-1,2,3-triazole (9). 1-Chloro-4-prop-2-ynyloxy-benzene and benzyl azide afforded 1-benzyl-4-(4-chlorophenoxymethyl)-1,2,3-triazole as white solid. Yield: $140.5 \mathrm{mg}$ (47\%). $102^{\circ} \mathrm{C}$ (lit. 102-103 ${ }^{\circ} \mathrm{C}$ ) [9]. IR (ATR) $v_{\max } / \mathrm{cm}^{-1}: 2945,2873,1582,1488,1458 .{ }^{1} \mathrm{H} \mathrm{NMR}$ $\left(300 \mathrm{MHz}, \mathrm{CDCl}_{3}\right) \delta / \mathrm{ppm}: 7.53(\mathrm{~s}, 1 \mathrm{H}), 7.38-7.40(\mathrm{~m}, 3 \mathrm{H})$, $7.27-7.30(\mathrm{~m}, 2 \mathrm{H}), 7.22-7.25(\mathrm{~d}, 2 \mathrm{H}, J=8.5 \mathrm{~Hz}), 6.89-6.92(\mathrm{~d}$, $2 \mathrm{H}, J=8.5 \mathrm{~Hz}), 5.54(\mathrm{~s}, 2 \mathrm{H}), 5.16(\mathrm{~s}, 2 \mathrm{H}) .{ }^{13} \mathrm{C} \mathrm{NMR}(75 \mathrm{MHz}$, $\mathrm{CDCl}_{3}$ ) $\delta / \mathrm{ppm}: 156.7,144.1,134.3,129.7,129.4,128.8,128.0$, 122.6, 116.0, 62.2, 54.2. MS $\left(\mathrm{EI}^{+}\right) \mathrm{m} / z(\%): 299[\mathrm{M}]^{+}(15)$, $91\left[\mathrm{C}_{6} \mathrm{H}_{5} \mathrm{CH}_{2}\right]^{+}(100), 144\left[\mathrm{C}_{10} \mathrm{H}_{10} \mathrm{~N}\right]^{+}(78), 172\left[\mathrm{C}_{10} \mathrm{H}_{10} \mathrm{~N}\right]^{+}$ (25).

1-Benzyl-4-(4-methoxyphenoxymethyl)-1,2,3-triazole (10).1-Methoxy-4-prop-2-ynyloxy-benzene and benzyl azide afforded 1-benzyl-4-(4-methoxy-phenoxymethyl)-1,2,3-triazole as white solid. Yield: $280.0 \mathrm{mg}$ (95\%). m.p. $92.1^{\circ} \mathrm{C}$ (lit. 92-93 ${ }^{\circ} \mathrm{C}$ ) [10]. IR (ATR) $\nu_{\max } / \mathrm{cm}^{-1}: 2946,2831,1505,1286 .{ }^{1} \mathrm{H}$ NMR $\left(300 \mathrm{MHz}, \mathrm{CDCl}_{3}\right) \delta / \mathrm{ppm}: 7.50(\mathrm{~s}, 1 \mathrm{H}), 7.37-7.38(\mathrm{~m}, 3 \mathrm{H})$, $7.23-7.26(\mathrm{~m}, 2 \mathrm{H}), 6.88-6.90(\mathrm{~d}, 2 \mathrm{H}, J=8.2 \mathrm{~Hz}), 6.78-6.87$ $(\mathrm{d}, 2 \mathrm{H}, J=8.2 \mathrm{~Hz}), 5.51(\mathrm{~s}, 2 \mathrm{H}), 5.12(\mathrm{~s}, 2 \mathrm{H}), 3.74(\mathrm{~s}, 3 \mathrm{H}) .{ }^{13} \mathrm{C}$ $\operatorname{NMR}\left(75 \mathrm{MHz}_{2} \mathrm{CDCl}_{3}\right.$ ) $\delta / \mathrm{ppm}: 154.2,152.3,144.8,134.5,129.1$, $128.8,128.1,122.6,115.9,114.7,62.8,54.2$. MS $\left(\mathrm{EI}^{+}\right) \mathrm{m} / z(\%)$ : $295[\mathrm{M}]^{+}(20), 144\left[\mathrm{C}_{10} \mathrm{H}_{10} \mathrm{~N}\right]^{+}(35), 124\left[\mathrm{C}_{7} \mathrm{H}_{8} \mathrm{O}_{2}\right]^{+}(100), 91$ $\left[\mathrm{C}_{6} \mathrm{H}_{5} \mathrm{CH}_{2}\right]^{+}(50)$. 
1-Benzyl-4-p-tolyloxymethyl-[1,2,3]triazole (11). 1-Methyl-4prop-2-ynyloxy-benzene and benzyl azide afforded 1-benzyl4-p-tolyloxymethyl-[1,2,3]triazole as white solid. Yield: $273.2 \mathrm{mg}$ (98\%). m.p. $109-110^{\circ} \mathrm{C}$. IR (ATR) $v_{\max } / \mathrm{cm}^{-1}: 2954$, 2919, 2869, 1607, 1287. ${ }^{1} \mathrm{H}$ NMR $\left(300 \mathrm{MHz}, \mathrm{CDCl}_{3}\right) \delta / \mathrm{ppm}$ : $7.50(\mathrm{~s}, 1 \mathrm{H}), 7.34-7.40(\mathrm{~m}, 3 \mathrm{H}), 7.24-7.27(\mathrm{~m}, 2 \mathrm{H}), 7.04-7.07$ $(\mathrm{d}, 2 \mathrm{H}, J=8.2 \mathrm{~Hz}), 6.83(\mathrm{~d}, 2 \mathrm{H}, J=8.2 \mathrm{~Hz}), 5.50(\mathrm{~s}, 2 \mathrm{H})$, $5.15(\mathrm{~s}, 2 \mathrm{H}), 2.27(\mathrm{~s}, 3 \mathrm{H}) .{ }^{13} \mathrm{C} \mathrm{NMR}\left(75 \mathrm{MHz}, \mathrm{CDCl}_{3}\right) \delta / \mathrm{ppm}$ : 156.1, 144.9, 134.5, 130.1, 129.9, 129.1, 128.7, 128.1, 122.5, 114.7, 62.3, 54.2. $\mathrm{MS}\left(\mathrm{EI}^{+}\right) \mathrm{m} / z(\%): 279[\mathrm{M}]^{+}(20), 91\left[\mathrm{C}_{6} \mathrm{H}_{5} \mathrm{CH}_{2}\right]^{+}$ (100).

1-Benzyl-4-phenoxymethyl-[1,2,3]triazole (12). Prop-2-ynyloxy-benzene and benzyl azide afforded 1-benzyl-4-phenoxymethyl-[1,2,3]triazole as white solid. Yield: $249.2 \mathrm{mg}(94 \%)$. m.p. 119-120 C. IR (ATR) $v_{\max } / \mathrm{cm}^{-1}: 2922,2872,1598,1490$. ${ }^{1} \mathrm{H}$ NMR $\left(300 \mathrm{MHz}, \mathrm{CDCl}_{3}\right.$ ) $\delta / \mathrm{ppm}$ : $7.52(\mathrm{~s}, 1 \mathrm{H}), 7.24-7.37$ (m, $7 \mathrm{H}), 6.73-6.97(\mathrm{~m}, 3 \mathrm{H}), 5.52(\mathrm{~s}, 2 \mathrm{H}), 5.17(\mathrm{~s}, 2 \mathrm{H}) .{ }^{13} \mathrm{C} \mathrm{NMR}$ $\left(75 \mathrm{MHz}, \mathrm{CDCl}_{3}\right) \delta / \mathrm{ppm}: 158.2,144.6,134.4,129.5,129.1,128.7$, 128.0, 121.2, 114.7, 62.0, 54.1. MS $\left(\mathrm{EI}^{+}\right) \mathrm{m} / z(\%): 265[\mathrm{M}]^{+}(5)$, $91\left[\mathrm{C}_{6} \mathrm{H}_{5} \mathrm{CH}_{2}\right]^{+}(100)$.

4-(1-Benzyl-1,2,3-triazol-4-ylmethoxy)-benzaldehyde (13). 4Prop-2-ynyloxy-benzaldehyde and benzyl azide afforded 4(1-benzyl-1,2,3-triazol-4-ylmethoxy)-benzaldehyde as white solid. Yield: $275.1 \mathrm{mg}(94 \%)$. m.p. $79^{\circ} \mathrm{C}$ (lit. $79-80^{\circ} \mathrm{C}$ ) [11]. IR (ATR) $v_{\max } / \mathrm{cm}^{-1}: 2821,2798,2731,1693,1653,1508$ (m), 1261. ${ }^{1} \mathrm{H}$ NMR $\left(300 \mathrm{MHz}, \mathrm{CDCl}_{3}\right.$ ) $\delta / \mathrm{ppm}: 9.88(\mathrm{~s}, 1 \mathrm{H}), 7.82-7.83$ $(\mathrm{dd}, 2 \mathrm{H}, J=3,9 \mathrm{~Hz}), 7.54(\mathrm{~s}, 1 \mathrm{H}), 7.36-7.38(\mathrm{~m}, 3 \mathrm{H}), 7.26-7.29$ $(\mathrm{m}, 2 \mathrm{H}), 7.07-7.09(\mathrm{dd}, 2 \mathrm{H}, J=3,9 \mathrm{~Hz}), 5.54(\mathrm{~s}, 2 \mathrm{H}), 5.26(\mathrm{~s}$, $2 \mathrm{H}) .{ }^{13} \mathrm{C}$ NMR $\left(75 \mathrm{MHz}, \mathrm{CDCl}_{3}\right.$ ) $\delta / \mathrm{ppm}: 190.7,163.3,143.6$, $134.3,130.9,130.3,129.2,128.9,128.2,123.1,115.3,62.2,54.3$. MS $\left(\mathrm{EI}^{+}\right) \mathrm{m} / z(\%): 293[\mathrm{M}]^{+}(5), 91\left[\mathrm{C}_{6} \mathrm{H}_{5} \mathrm{CH}_{2}\right]^{+}(100)$.

Butyl-carbamic Acid 1-Benzyl-[1,2,3]triazol-4-ylmethyl Ester (14). Butyl-carbamic acid prop-2-enyl ester and benzyl azide afforded butyl-carbamic acid 1-benzyl-1H-[1,2,3]triazol-4ylmethyl ester as white solid. Yield: $267.9 \mathrm{mg}$ (93\%). m.p. 99$100^{\circ} \mathrm{C}$. IR (ATR) $v_{\max } / \mathrm{cm}^{-1}: 2958,2930,2868,1684,1531 .{ }^{1} \mathrm{H}$ NMR (300 MHz, $\left.\mathrm{CDCl}_{3}\right) \delta / \mathrm{ppm}$ : $7.54(\mathrm{~s}, 1 \mathrm{H}), 7.28-7.41(\mathrm{~m}$, $3 \mathrm{H}), 7.26(\mathrm{~m}, 2 \mathrm{H}), 5.54(\mathrm{~s}, 2 \mathrm{H}), 5.15(\mathrm{~s}, 2 \mathrm{H}), 4.81(\mathrm{~s}$, broad, $1 \mathrm{H}), 3.15(\mathrm{~m}, 2 \mathrm{H}), 1.44(\mathrm{~m}, 2 \mathrm{H}), 1.25(\mathrm{~m}, 2 \mathrm{H}), 0.87(\mathrm{t}, 3 \mathrm{H}) .{ }^{13} \mathrm{C}$ NMR (75 MHz, $\left.\mathrm{CDCl}_{3}\right)$ S/ppm: 156.1, 143.9, 134.5, 129.1, 128.7, 128.1, 123.5, 57.7, 54.1, 40.7, 31.9, 19.8, 13.6. $\mathrm{MS}_{\left(\mathrm{EI}^{+}\right)} \mathrm{m} / z$ (\%): $288[\mathrm{M}]^{+}(10), 91\left[\mathrm{C}_{6} \mathrm{H}_{5} \mathrm{CH}_{2}\right]^{+}(100)$.

\section{Results and Discussion}

As mentioned above, the first observations were made on the reaction of 1,3-diazido-propan-2-ol $\mathbf{1}$ with phenylacetylene 2 in the presence of catalytic amounts of CuI to afford 1,3-bis(4-phenyl-[1,2,3]triazol-1-yl)-propan-2-ol, compound 3 . The difficulties found in the work-up process to separate the copper salt motivated us to change the copper salt ratio. Thus, when an equimolar amount of $\mathrm{CuI}$ was used in the reaction, an insoluble precipitate was formed after $24 \mathrm{~h}$. A reexamination of these last conditions permitted us to establish a general procedure where the straightforward

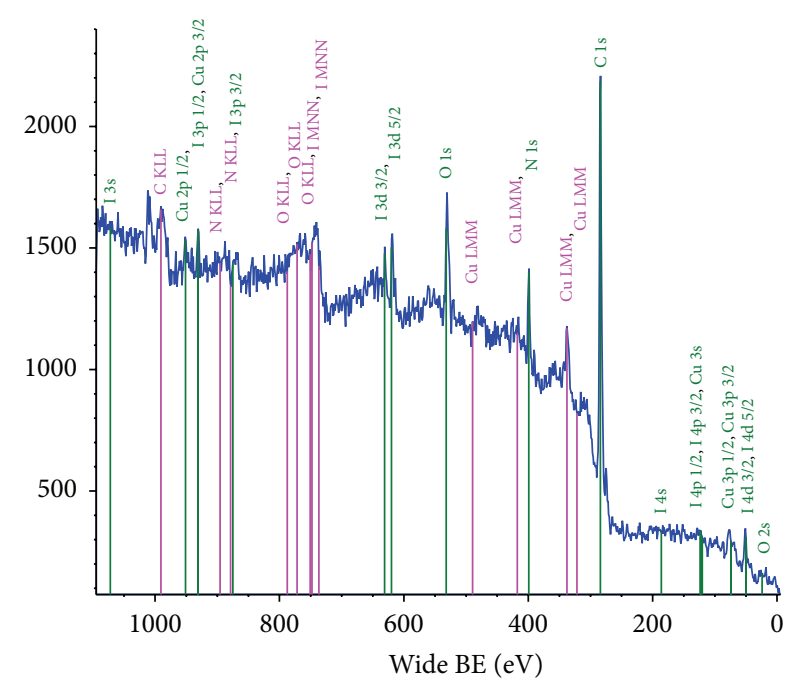

FIGURE 1: Survey spectra of the reaction product 4.

mixing of CuI, alkyne $\mathbf{1}$, and azide $\mathbf{2}$ generated the polymeric copper complex 4 whose structure is proposed in Scheme 1. The formation of analogous coordination polymers has been reported by Reiser [12] and Zink [13] groups, with a halogenbridged $\mathrm{Cu}_{2} \mathrm{X}_{2}$-type structure for this kind of compounds [14-16].

In order to determine the chemical environment surrounding copper ion and evaluate a possible interaction I-Cu$\mathrm{N}$ in the complex, XPS analysis was performed on product 4. Figure 1 shows that the survey spectra of the product, the usual signals of $\mathrm{Cu} 2 \mathrm{p} 3 / 2(934.424 \mathrm{eV}), \mathrm{N}$ 1s $(402 \mathrm{eV}), \mathrm{C} 1 \mathrm{~s}$ $(284.5 \mathrm{eV})$, and I $3 \mathrm{~d} 5 / 2(618.88 \mathrm{eV})$, are easily identified.

In addition, this study confirms the presence of the cited elements involved in the product, which is proposed as a complex between $\mathrm{CuI}$ and the bistriazole system. A narrow spectra focused on the $\mathrm{Cu} 2 \mathrm{p} \mathrm{3/2}$ region (Figure 2) obtained to analyze the possible interactions of copper; the signal of copper appears with a center of $934.424 \mathrm{eV}$. A noteworthy characteristic is the existence of 2 satellite peaks at $941 \mathrm{eV}$ and $944.9 \mathrm{eV}$; these satellites are well known to appear when copper is forming complexes especially with nitrogen, characteristic of $\mathrm{Cu}^{+2}$ species surrounded by electron donor nitrogen atoms [17]. However, the HWFM of the copper signal exhibits at least 2 signals, so a curve fit was performed and it resolved 2 signals at $934.366 \mathrm{eV}$ and $932.734 \mathrm{eV}$, close to other $\mathrm{Cu}^{+1}$ signals observed at $931.7 \mathrm{eV}$ [18]. The chemical shift observed in the study confirms the interaction in the proposed copper complex 4 bearing both $\mathrm{Cu}-\mathrm{N}$ and $\mathrm{Cu}-$ I interactions [17, 19]; this was further supported with the analysis of the iodine and nitrogen regions as shown in Figures 1 and 2.

Moreover, the iodine $3 \mathrm{~d} 5 / 2$ region shows a signal at $618.88 \mathrm{eV}$ coincident to $619 \mathrm{eV}$ signal reported for a $\mathrm{Cu}-\mathrm{I}$ interaction $[17,19]$, which allows us to conclude that this interaction is still present, confirming that compound $\mathbf{4}$ has not undergone a chemical change. The $\mathrm{N}$ 1s region was also analyzed and a curve fit was performed (Figure 3); 3 signals were obtained as expected, since the complex structure 


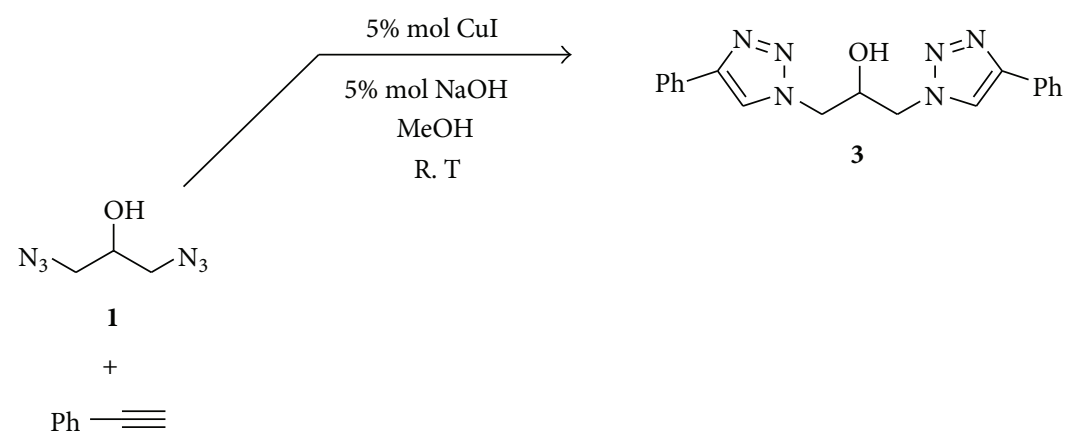

2

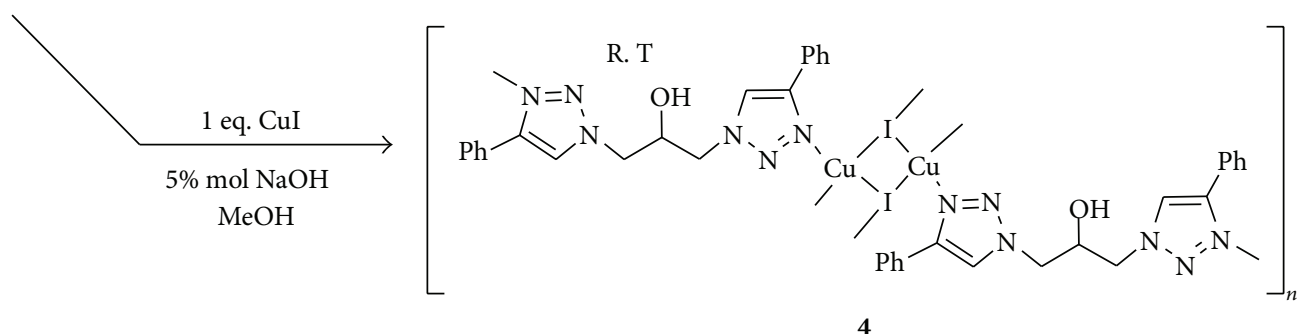

Scheme 1: Cycloaddition between azide 2 and alkyne $\mathbf{1}$ using catalytic and equimolar amounts of CuI.

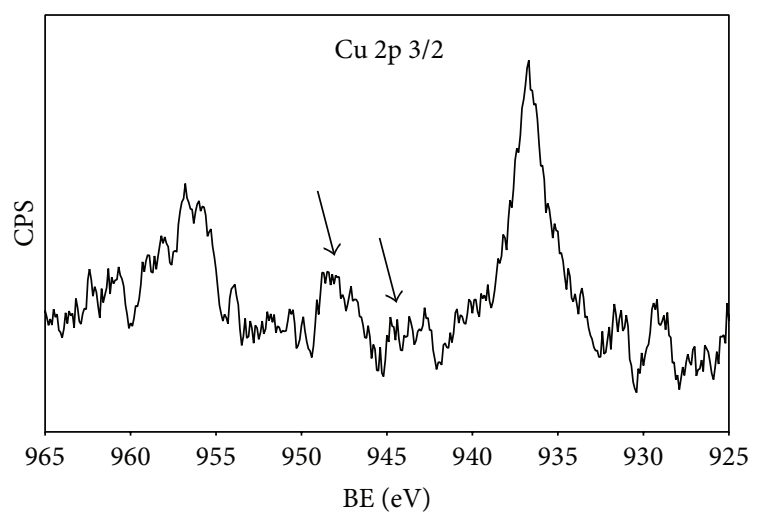

Figure 2: Narrow spectra of $\mathrm{Cu} 2 \mathrm{p} 3 / 2$ region showing the characteristic copper signal and 2 satellites attributed to the $\mathrm{Cu}-\mathrm{N}$ interaction of the formed complex 4.

proposed would consist of nitrogen with 3 different chemical environments, a first N-Cu-I interaction and 2 additional nitrogen signals which form part of the triazole molecule but without any interaction with $\mathrm{Cu}$, confirming the formation of the complex proposed.

Other outstanding property observed in compound $\mathbf{4}$ is the high thermal stability. This behavior was determined by TG curves analysis for complex $\mathbf{4}$ which displays an important weight loss around $320-400^{\circ} \mathrm{C}$, associated with the compound degradation and similar to that described by Cavalheiro and coworkers [20]. In contrast, the TGA curve for copper-free bistriazole 3 indicates only a slight loss presumably due to volatile solvents and humidity (Figure 4).

DSC studies were determined on copper complex 4 and copper-free bistriazole 3 and the corresponding DSC curves

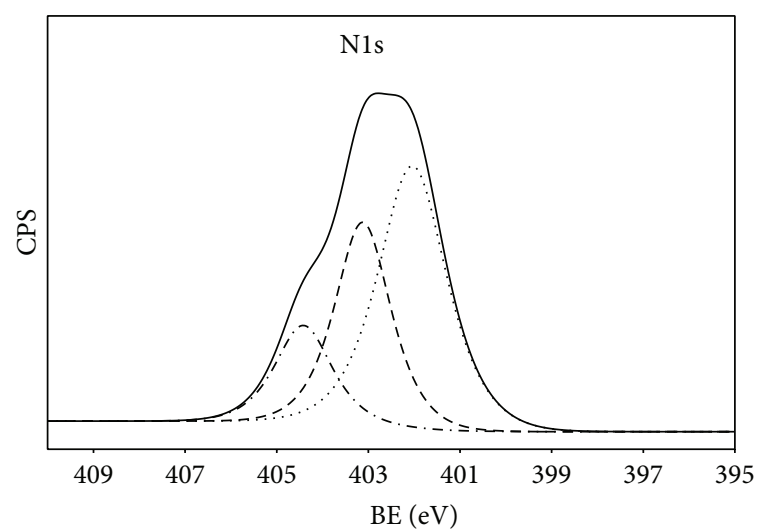

FIGURE 3: XPS curve fit spectra of the $\mathrm{N}$ 1s region in compound 4.

are plotted in Figure 5. For compound 3, DSC profile denotes an endothermic process at $243^{\circ} \mathrm{C}$ assigned to the product melting point and an exotherm at $369^{\circ} \mathrm{C}$, showing decomposition thereof. In the case of complex 4 , an exotherm observed at $320^{\circ} \mathrm{C}$ shows the compound decomposition, followed by two endothermic processes, 379 and $397^{\circ} \mathrm{C}$ associated copper loss and degradation; a third point of decomposition can be found at $598^{\circ} \mathrm{C}$ corresponding to the decomposition of the compound. This decomposition pattern is analogous to a copper(II) coordination polymer containing tetrazole ligands [21]. Hence, DSC results support TGA studies and suggest stability for bistriazole copper complex 4.

Although crystallization of copper complex 4 was not possible, we realized that this compound produces an aggregate with a specific supramolecular structure. In the SEM micrographs obtained from compound 4 (Figure 6), a triangular-shaped morphology is presented, which could 


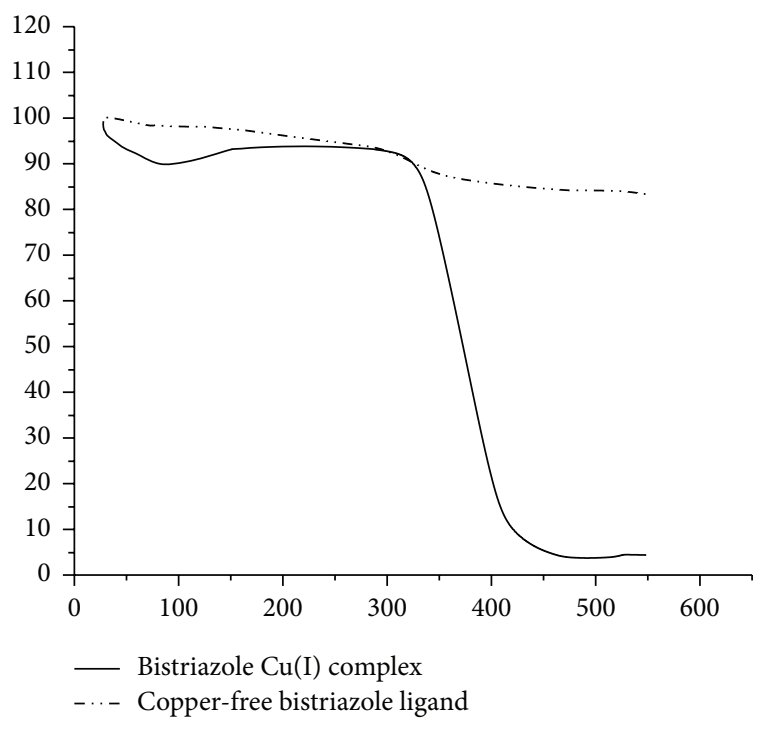

FIGURE 4: TG thermograms of copper-free bistriazole 3 and complex 4.

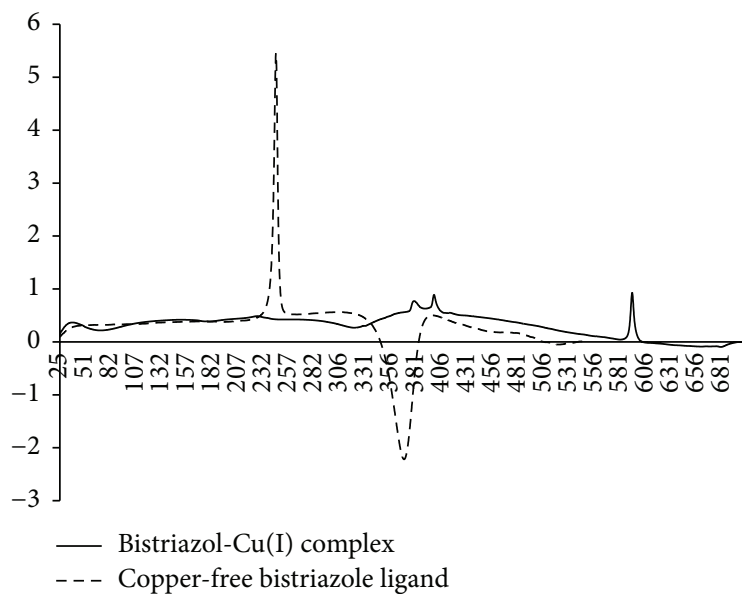

FIGURE 5: DSC curves for copper-free bistriazole 3 and complex 4.

be generated by metamorphic transformations during the synthesis. This well-defined architecture is consequence of metal-ligand interactions and suggests a kind of selforganization [22].

The catalytic activity of copper complex 4 was tested in the reaction between phenylacetylene 2 and benzyl azide 5 which were treated with varying catalyst quantities (Scheme 2). In all cases, the formation of triazole 6 was registered as only reaction product, and the results, summarized in Table 1, demonstrate that complex 4 efficiently catalyzes the $\mathrm{CuAAC}$ reaction on a wide range of solvents. Even though the reaction proceeded with $0.5 \%$ mol catalyst, the optimal conditions were obtained using a $2.5 \%$ mol catalyst ratio. From these results, we selected $\mathrm{CH}_{2} \mathrm{Cl}_{2}$ as reaction solvent for subsequent experiments.

The breadth of this process was also studied. Examples in Table 2 and Scheme 3 proved that compound 4 works with
TABLE 1: Synthesis of triazole 6 catalyzed by copper complex 4 .

\begin{tabular}{|c|c|c|c|}
\hline Entry & Catalyst ratio $(\% \mathrm{~mol})$ & Solvent & $\%$ yield \\
\hline 1 & 0.5 & $\mathrm{CH}_{2} \mathrm{Cl}_{2}$ & 80 \\
\hline 2 & 1.0 & $\mathrm{CH}_{2} \mathrm{Cl}_{2}$ & 89 \\
\hline 3 & 2.5 & $\mathrm{CH}_{2} \mathrm{Cl}_{2}$ & 100 \\
\hline 4 & 5.0 & $\mathrm{CH}_{2} \mathrm{Cl}_{2}$ & 100 \\
\hline 5 & 0.5 & $\mathrm{H}_{2} \mathrm{O}$ & 35 \\
\hline 6 & 1.0 & $\mathrm{H}_{2} \mathrm{O}$ & 43 \\
\hline 7 & 2.5 & $\mathrm{H}_{2} \mathrm{O}$ & 100 \\
\hline 8 & 5.0 & $\mathrm{H}_{2} \mathrm{O}$ & 100 \\
\hline 9 & 0.5 & Acetone & 40 \\
\hline 10 & 1.0 & Acetone & 60 \\
\hline 11 & 2.5 & Acetone & 100 \\
\hline 12 & 5.0 & Acetone & 100 \\
\hline 13 & 0.5 & THF & 45 \\
\hline 14 & 1.0 & THF & 70 \\
\hline 15 & 2.5 & THF & 95 \\
\hline 16 & 5.0 & THF & 100 \\
\hline 17 & 0.5 & DMF & 46 \\
\hline 18 & 1.0 & DMF & 69 \\
\hline 19 & 2.5 & DMF & 96 \\
\hline 20 & 5.0 & $\mathrm{DMF}$ & 100 \\
\hline 21 & 0.5 & AcOEt & 30 \\
\hline 22 & 1.0 & AcOEt & 60 \\
\hline 23 & 2.5 & AcOEt & 93 \\
\hline 24 & 5.0 & AcOEt & 96 \\
\hline 25 & 0.5 & $\mathrm{MeOH}$ & 40 \\
\hline 26 & 1.0 & $\mathrm{MeOH}$ & 50 \\
\hline 27 & 2.5 & $\mathrm{MeOH}$ & 96 \\
\hline 28 & 5.0 & $\mathrm{MeOH}$ & 100 \\
\hline 29 & 2.5 & $\mathrm{EtOH}$ & 96 \\
\hline 30 & 5.0 & $\mathrm{EtOH}$ & 100 \\
\hline 31 & 2.5 & $n \mathrm{PrOH}$ & 94 \\
\hline 32 & 5.0 & $n \mathrm{PrOH}$ & 100 \\
\hline 33 & 2.5 & $\mathrm{CHCl}_{3}$ & 94 \\
\hline 34 & 5.0 & $\mathrm{CHCl}_{3}$ & 100 \\
\hline 35 & 2.5 & $\mathrm{CH}_{3} \mathrm{CN}$ & 93 \\
\hline 36 & 5.0 & $\mathrm{CH}_{3} \mathrm{CN}$ & 100 \\
\hline 37 & 2.5 & $\mathrm{Et}_{2} \mathrm{O}$ & 94 \\
\hline 38 & 5.0 & $\mathrm{Et}_{2} \mathrm{O}$ & 100 \\
\hline
\end{tabular}

different alkynes to afford the respective benzyl triazoles in high yields.

The insoluble nature of copper complex 4 prompted us to explore the possibility of use like heterogeneous catalyst. In this regard, the recycling experiments were carried out by simple filtration of insoluble catalyst which was reincorporated to the next cycle. The results in Table 3 suggest that comparatively good yields can be obtained after 5 cycles in spite of the progressive loss of efficiency. This peculiarity allows copper complex 4 to be used without other additives in similar way to other available catalytic systems designed for CuAAC reactions [23]. 


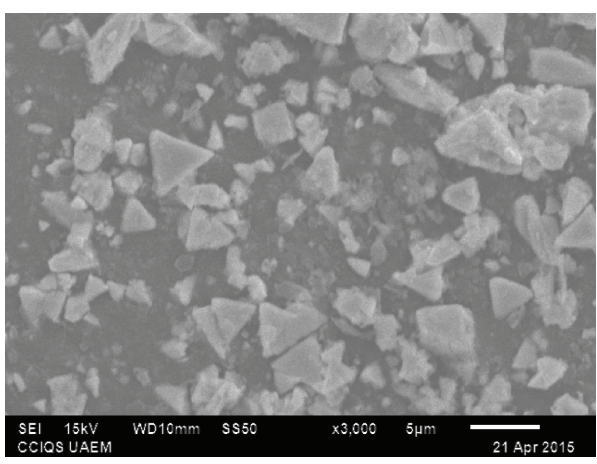

(a)

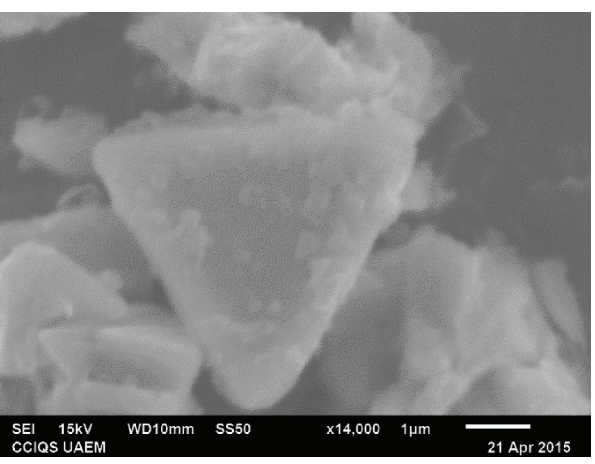

(b)

FiguRE 6: SEM micrographs complex 4. (a) $\times 3000,5 \mu \mathrm{m}$ and (b) $\times 14000,1 \mu \mathrm{m}$.

TABLE 2: Synthesis of triazoles catalyzed by copper complex 4 (see Scheme 3).

\begin{tabular}{lcc}
\hline Compound & $\mathrm{R}$ & \% yield \\
\hline $\mathbf{6}$ & & 100 \\
$\mathbf{7}$ & & 95 \\
$\mathbf{8}$ & $\mathrm{CH}_{2} \mathrm{O}(4-\mathrm{Br}) \mathrm{C}_{6} \mathrm{H}_{4}$ & 34 \\
$\mathbf{9}$ & $\mathrm{CH}_{2} \mathrm{O}\left(4-\mathrm{Cl}_{6}\right) \mathrm{C}_{6} \mathrm{H}_{4}$ & 47 \\
$\mathbf{1 0}$ & $\mathrm{CH}_{2} \mathrm{O}\left(4-\mathrm{OCH}_{3}\right) \mathrm{C}_{6} \mathrm{H}_{4}$ & 95 \\
$\mathbf{1 1}$ & $\mathrm{CH}_{2} \mathrm{O}\left(4-\mathrm{CH}_{3}\right) \mathrm{C}_{6} \mathrm{H}_{4}$ & 98 \\
$\mathbf{1 2}$ & $\mathrm{CH} \mathrm{OC}_{6} \mathrm{H}_{5}$ & 94 \\
$\mathbf{1 3}$ & $\mathrm{CH}_{2} \mathrm{O}\left(4-\mathrm{CHO}_{2} \mathrm{C}_{6} \mathrm{H}_{4}\right.$ & 94 \\
$\mathbf{1 4}$ & $\mathrm{CH}_{2} \mathrm{OCONH}\left(\mathrm{CH}_{2}\right)_{3} \mathrm{CH}_{3}$ & 93 \\
\hline
\end{tabular}

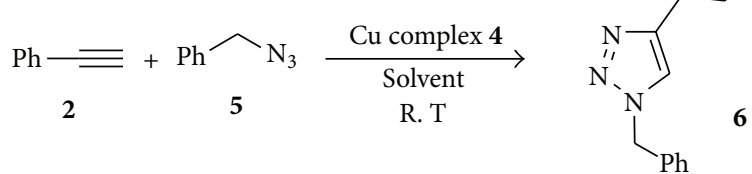

Scheme 2: Cycloaddition between azide 5 and alkyne 2 using copper complex 4.

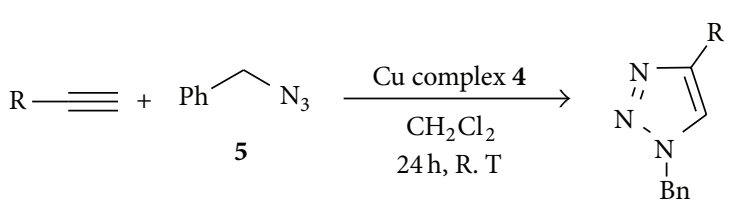

SCHEME 3

\section{Conclusions}

A simple synthetic protocol which involves the direct combination of three reagents ("components") was developed to provide a new bistriazole copper complex which shows catalytic activity for $\mathrm{CuAAC}$ reactions and can be recycled at
TABLE 3: Recycling of copper complex 4 in the synthesis of triazole 6.

\begin{tabular}{lc}
\hline Cycle & \% yield \\
\hline 1 & 100 \\
2 & 99 \\
3 & 98 \\
4 & 95 \\
5 & 91 \\
6 & 85 \\
7 & 76 \\
8 & 57 \\
\hline
\end{tabular}

least for 4 times maintaining its catalytic ability; in addition, this complex exhibits a precise morphology, product of a selforganization, besides a high thermal stability which opens wide perspectives of promising applications in the future. The multicomponent reaction strategy for the synthesis of this copper complex represents a departure point for the preparation of similar compounds from nonexpensive starting materials in a one-pot process; these elements suggest that this approach will enjoy widespread use.

\section{Competing Interests}

The authors declare that they have no competing interests.

\section{Acknowledgments}

Financial support from CONACYT (Project no. 135053) is gratefully acknowledged. The authors would like to thank Signa S. A. de C. V., N. Zavala, A. Nuñez, and L. Triana, for the technical support.

\section{References}

[1] J. Zhu and H. Bienaymé, Multicomponent Reactions, WileyVCH, Weinheim, Germany, 1st edition, 2005.

[2] A. Dömling, W. Wang, and K. Wang, "Chemistry and biology of multicomponent reactions," Chemical Reviews, vol. 112, no. 6, pp. 3083-3135, 2012. 
[3] A. Dömling and I. Ugi, "Multicomponent reactions with isocyanides," Angewandte Chemie-International Edition, vol. 39, no. 18, pp. 3169-3210, 2000.

[4] B. B. Touré and D. G. Hall, "Natural product synthesis using multicomponent reaction strategies," Chemical Reviews, vol. 109, no. 9, pp. 4439-4486, 2009.

[5] R.-G. Xiong, X. Xue, H. Zhao, X.-Z. You, B. F. Abrahams, and Z. Xue, "Novel, acentric metal-organic coordination polymers from hydrothermal reactions involving in situ ligand synthesis," Angewandte Chemie-International Edition, vol. 41, no. 20, pp. 3800-3803, 2002.

[6] J. Lahann, Click Chemistry for Biotechnology and Materials Science, John Wiley \& Sons, Chichester, UK, 1st edition, 2009.

[7] A. R. Katritzky, S. K. Singh, N. K. Meher et al., "Triazoleoligomers by 1,3-dipolar cycloaddition," ARKIVOC, vol. 2006, no. 5, pp. 43-62, 2006.

[8] H. Gallardo, G. Conte, F. Bryk, M. C. S. Lourenço, M. S. Costac, and V. F. Ferreira, "Synthesis and evaluation of 1-alkyl-4-phenyl[1,2,3]-triazole derivatives as antimycobacterial agent," Journal of the Brazilian Chemical Society, vol. 18, no. 6, pp. 1285-1291, 2007.

[9] Y. Jang, X. Chen, L. Qu et al., "An efficient ultrasoundassisted method for the synthesis of 1,4-disubstituted triazoles," Zeitschritffür Naturforschung B, vol. 66b, no. 1, pp. 77-82, 2011.

[10] B. R. Buckley, S. E. Dann, D. P. Harris, H. Heaney, and E. C. Stubbs, "Alkynylcopper(I) polymers and their use in a mechanistic study of alkyne-azide click reactions," Chemical Communications, vol. 46, no. 13, pp. 2274-2276, 2010.

[11] M. A. García, Z. G. Ríos, J. González et al., "The use of glucose as alternative reducing agent in copper-catalyzed alkyne-azide cycloaddition," Letters in Organic Chemistry, vol. 8, no. 10, pp. 701-706, 2011.

[12] M. Liu and O. Reiser, "A copper(I) isonitrile complex as a heterogeneous catalyst for azide-alkyne cycloaddition in water," Organic Letters, vol. 13, no. 5, pp. 1102-1105, 2011.

[13] M. Henary, J. L. Wootton, S. I. Khan, and J. I. Zink, "Structure and assignment of the luminescence of a new mixed-ligand copper(I) polymer," Inorganic Chemistry, vol. 36, no. 5, pp. 796801, 1997.

[14] P. Aslanidis, P. J. Cox, S. Divanidis, and A. C. Tsipis, "Copper(I) halide complexes with 1,3-propanebis(diphenylphosphine) and heterocyclic thione ligands: crystal and electronic structures (DFT) of $[\mathrm{CuCl}(\mathrm{pymtH})(\mathrm{dppp})],[\mathrm{CuBr}(\mathrm{pymtH})(\mathrm{dppp})]$, and $[\mathrm{Cu}(\mu-\mathrm{I})(\mathrm{dppp})]_{2}, "$ Inorganic Chemistry, vol. 41, no. 25, pp. 6875-6886, 2002.

[15] H. Araki, K. Tsuge, Y. Sasaki, S. Ishizaka, and N. Kitamura, "Luminescence ranging from red to blue: a series of copper(I)halide complexes having rhombic $\left\{\mathrm{Cu}_{2}(\mu-\mathrm{X})_{2}\right\}(\mathrm{X}=\mathrm{Br}$ and I) units with $\mathrm{N}$-heteroaromatic ligands," Inorganic Chemistry, vol. 44, no. 26, pp. 9667-9675, 2005.

[16] D. M. Zink, M. Bächle, T. Baumann et al., "Synthesis, structure, and characterization of dinuclear copper(I) halide complexes with $\mathrm{P}^{\mathrm{N}}$ ligands featuring exciting photoluminescence properties," Inorganic Chemistry, vol. 44, no. 5, pp. 2292-2305, 2013.

[17] D. G. Brown and U. Weser, "XPS spectra of copper and nickel biuret complexes-observations of intense satellite structure in the $2 \mathrm{P}$ spectrum of a Copper(III) system," Zeitschrift für Naturforschung B, vol. 34, no. 7, pp. 9667-9675, 1979.

[18] R. Clarke, K. Latham, C. Rix, M. Hobday, and J. White, "Novel copper materials based on the self-assembly of organophosphonic acids and bidentate amines," CrystEngComm, vol. 7, pp. 2836, 2005.
[19] NIST Standard Reference Database 20, Version 4.1.

[20] É. T. G. Cavalheiro, F. C. D. Lemos, J. Z. Schpector, and E. R. Dockal, "The thermal behaviour of nickel, copper and zinc complexes with the Schiff bases cis- and trans- $N, N^{\prime}$ bis(salicylidene)-1,2-ciclohexadiamine (Salcn)," Thermochimica Acta, vol. 370, no. 1-2, pp. 129-133, 2001.

[21] V. Hartdegen, T. M. Klapötke, and S. M. Sproll, "Synthesis and characterization of a three-dimensional coordination polymer based on copper(II) nitrate and a tridentate tetrazole ligand," Zeitschrift für Naturforschung, vol. 64, no. 11-12, pp. 1535-1541, 2009.

[22] S. Mann and G. A. Ozin, "Synthesis of inorganic materials with complex form," Nature, vol. 382, no. 6589, pp. 313-318, 1996.

[23] H. López-Ruiz, J. E. de La Cerda-Pedro, S. Rojas-Lima et al., "Cuprous oxide on charcoal-catalyzed ligand-free synthesis of 1,4-disubstituted 1,2,3-triazoles via click chemistry," Arkivoc, vol. 2013, no. 3, pp. 139-164, 2013. 

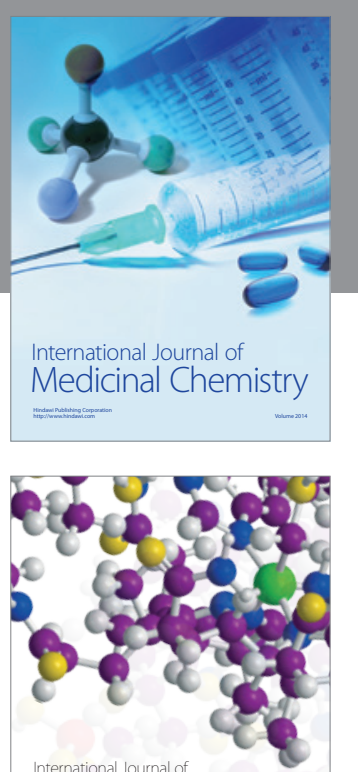

Carbohydrate Chemistry

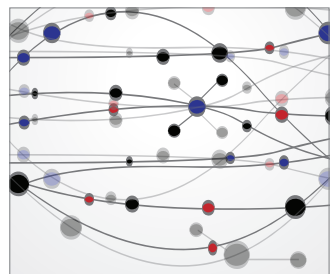

The Scientific World Journal
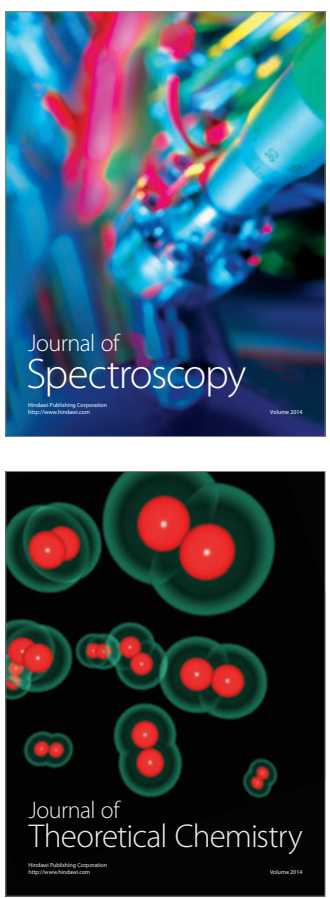
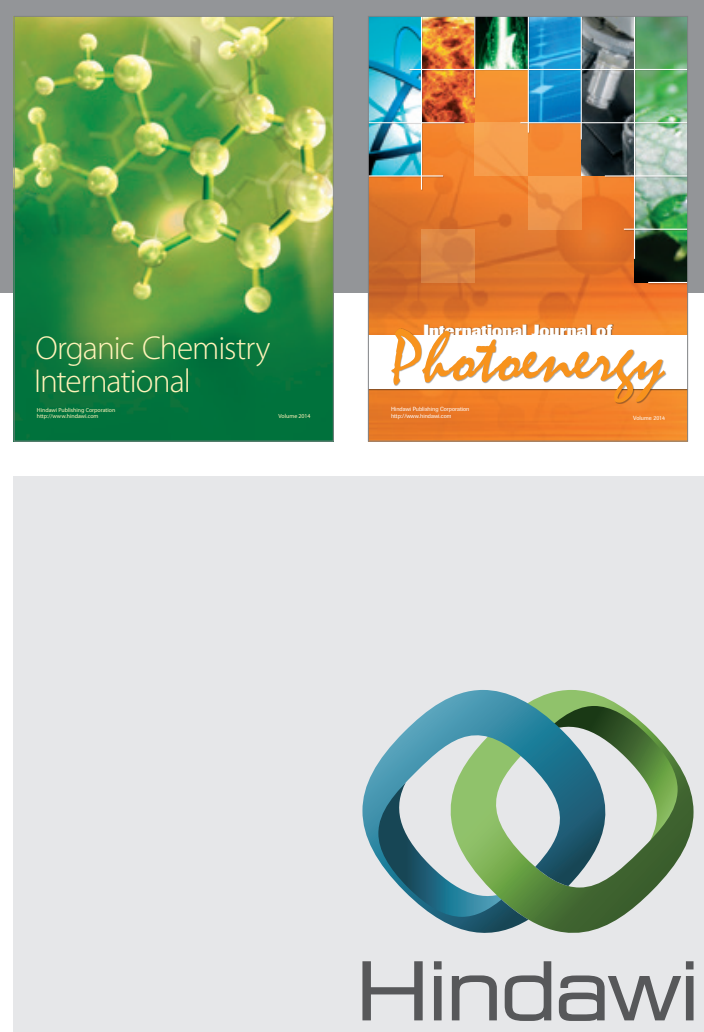

Submit your manuscripts at

http://www.hindawi.com

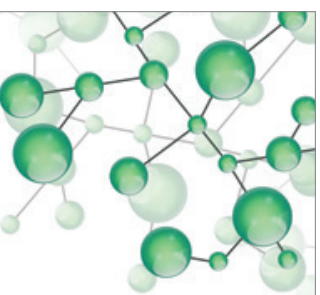

International Journal of

Inorganic Chemistry

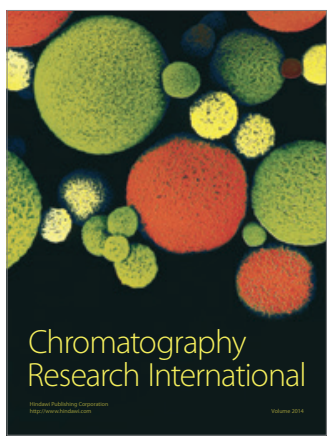

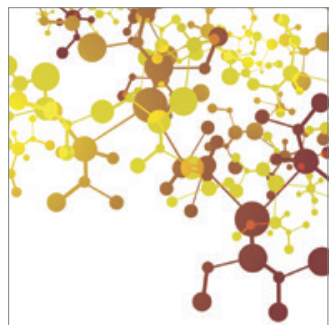

Applied Chemistry
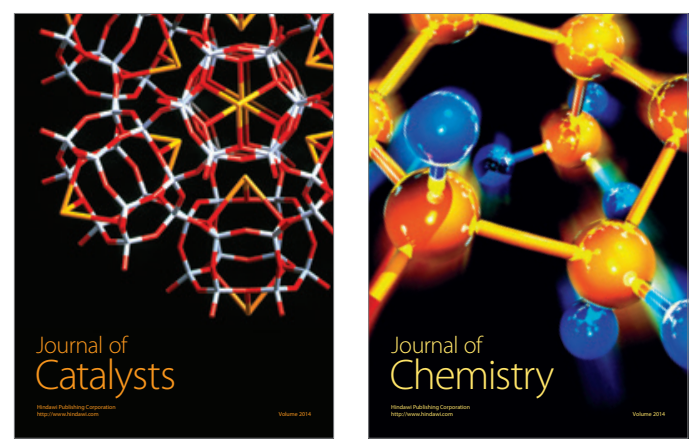
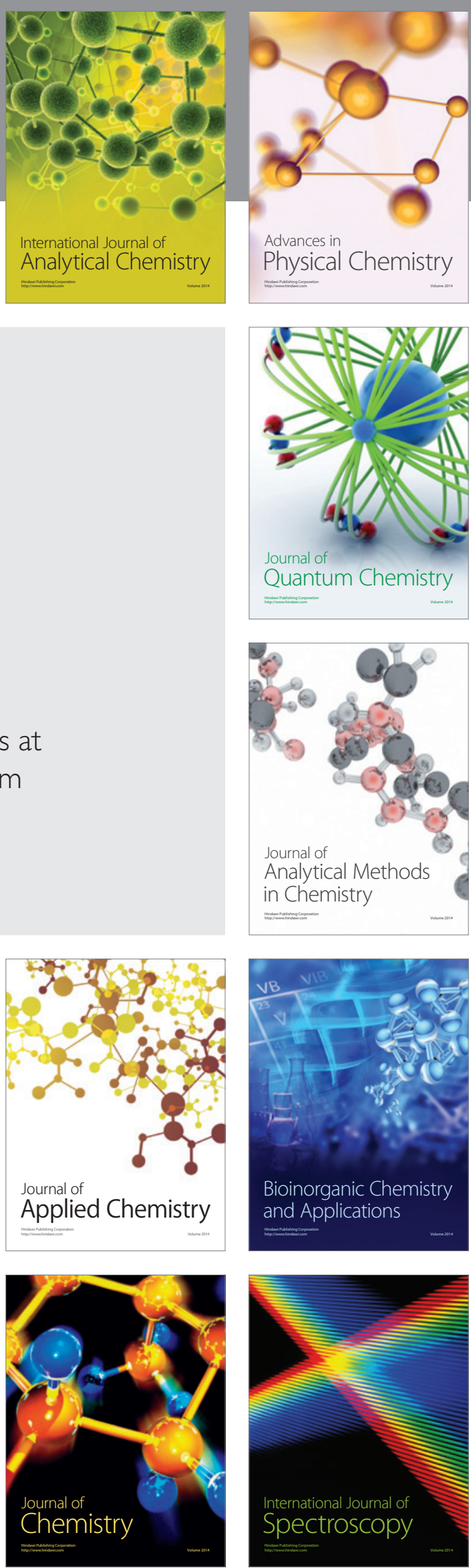